\title{
Effect of synovial fluid hyaluronan on the clearance of albumin from the canine knee
}

\author{
Stephen L Myers
}

The synovial fluid concentration of a variety of macromolecules derived from the matrix of the articular cartilage, including matrix proteins, ${ }^{1}$ proteoglycan fragments, ${ }^{2}$ and glycosaminoglycans, ${ }^{3}$ has been related to the magnitude of cartilage destruction or repair in arthritic joints. ${ }^{34}$ One determinant of the concentration of these molecules in the synovial fluid is their rate of release from the cartilage, and they serve as practical molecular 'markers' of disease in studies of osteoarthritis ${ }^{5}$ and rheumatoid arthritis. ${ }^{4}$ However, marker concentration in synovial fluid specimens also depends on factors that influence the clearance of the molecule from the synovial fluid. These include the volume of fluid within the joint space, synovial blood flow and inflammation, joint motion and, potentially, the composition of the synovial fluid. ${ }^{6}$ Unless these factors are taken into account, differences in marker concentration seen in serial samples of synovial fluid may misrepresent the metabolic status of the articular cartilage. ${ }^{56}$

Cartilage derived marker molecules and most proteins, for example albumin, appear to be removed from the joint space at approximately the same rate. ${ }^{6}$ Thus when ${ }^{131}$ I-labelled serum albumin (RISA) is injected into the knee its clearance kinetics approximate those of marker clearance from the joint space ${ }^{6}{ }^{7}$ In the present study we examined the relationship between the composition of the joint fluid (the concentration and average molecular weight of the hyaluronan therein) and the kinetics of RISA clearance from the normal knee.

\section{Materials and methods}

HYALURONAN IN CANINE SYNOVIAL FLUID

The knees of normal dogs (13-25 kg) were aspirated to obtain $0.05-0.25 \mathrm{ml}$ of synovial fluid, and repeated saline lavage of the joint was used to recover all remaining synovial fluid. The uronic acid concentration and intrinsic viscosity of these specimens were measured to determine the hyaluronan concentration and content of the synovial fluid, and hyaluronan average molecular weight.

\section{MANIPULATION OF SYNOVIAL FLUID}

HYALURONAN

The right knee, and one week later the left knee, of 13 beagle dogs (13-15 kg) was injected with $0.5 \mathrm{ml}$ of a preparation of saline and $5 \mu \mathrm{Ci}$ RISA that contained $0.03 \mathrm{mg} / \mathrm{ml}$ or $3.0 \mathrm{mg} / \mathrm{ml}$ of $6 \times 10^{6} \mathrm{Da}$ hyaluronan (RISA-HA $A_{\mathrm{H}}$ ), or $0.3 \mathrm{mg} / \mathrm{ml}$ or $3.0 \mathrm{mg} / \mathrm{ml}$ of $2 \times 10^{5} \mathrm{Da}$ hyaluronan (RISA-HA $\mathrm{L}_{\mathrm{L}}$ ). The table shows the pairing of injections. The resulting concentration of hyaluronan in the synovial fluid was measured $(t=0)$.

DETERMINATION OF RISA CLEARANCE

After each injection of RISA, hourly measurements of iodine-131 (cpm) were taken over the anterolateral aspect of the joint for seven hours, at which time $(t=7 \mathrm{~h})$ all available synovial fluid was aspirated and its volume and radioactivity $(\mathrm{cpm} / \mathrm{ml})$ were determined. The hyaluronan concentration and intrinsic viscosity of representative samples were measured, and the apparent distribution volume $(V \mathrm{~d})$ and clearance $(\mu \mathrm{l} / \mathrm{min})$ of RISA were calculated as described by Simkin. ${ }^{7}$

\section{Results}

In specimens of synovial fluid from normal dogs the concentration of hyaluronan averaged 2.9 (SD 0.5$) \mathrm{mg} / \mathrm{ml}$, and its average molecular mass was $1.4 \times 10^{6} \mathrm{Da}$. Because joint aspiration has been shown to underestimate the volume of fluid present in the joint, ${ }^{7}$ saline lavage was used to determine that $0.5-1.7 \mathrm{mg}$ of hyaluronan could be recovered from the normal canine knee; recovery from right and left knees was similar (figure). A strong correlation was seen between the amount of hyaluronan recovered and body weight
Rheumatology Division, Indiana University School of Medicine, Indianapolis, USA S L Myers

Correspondence to: Indiana University, School of Medicine, 541 Clinical Drive, Room 492, Room 492, IN 46202-5103, USA.
Comparison of distribution volume and clearance rate of ${ }^{131}$ I-labelled serum albumin (RISA), and volume of synovial fluid aspirated seven hours after $0.5 \mathrm{ml}$ of a mixture of RISA and hyaluronan was injected into the canine knee

\begin{tabular}{|c|c|c|c|c|c|c|c|c|c|c|}
\hline \multirow[t]{2}{*}{$\begin{array}{l}\text { No of } \\
\text { dogs }\end{array}$} & \multicolumn{2}{|c|}{$\begin{array}{l}\text { RISA-hyaluronan } \\
\text { preparation injected } \\
\text { into knee }(\mathrm{mg} / \mathrm{ml})\end{array}$} & \multicolumn{2}{|c|}{$\begin{array}{l}\text { Hyaluronan concn } \\
\text { in injected knee at } \\
\mathrm{t}=O \mathrm{~h}(\mathrm{mg} / \mathrm{ml})\end{array}$} & \multicolumn{2}{|c|}{$\begin{array}{l}\text { RISA } \\
\text { distribution } \\
\text { volume }(\mathrm{ml})\end{array}$} & \multicolumn{2}{|l|}{$\begin{array}{l}\text { RISA } \\
\text { clearance } \\
(\mu / \text { min) }\end{array}$} & \multicolumn{2}{|c|}{$\begin{array}{l}\text { Volume of synovial } \\
\text { fluid aspirated } \\
\text { at } \mathrm{t}=7 \mathrm{~h}(\mathrm{ml})\end{array}$} \\
\hline & $\begin{array}{l}\text { Right } \\
\text { knee }\end{array}$ & $\begin{array}{l}\text { Left } \\
\text { knee }\end{array}$ & $\begin{array}{l}\text { Right } \\
\text { knee }\end{array}$ & $\begin{array}{l}\text { Left } \\
\text { knee }\end{array}$ & $\begin{array}{l}\text { Right } \\
\text { knee }\end{array}$ & $\begin{array}{l}\text { Left } \\
\text { knee }\end{array}$ & $\begin{array}{l}\text { Right } \\
\text { knee }\end{array}$ & $\begin{array}{l}\text { Left } \\
\text { knee }\end{array}$ & $\begin{array}{l}\text { Right } \\
\text { knee }\end{array}$ & $\begin{array}{l}\text { Left } \\
\text { knee }\end{array}$ \\
\hline $\begin{array}{l}4 \\
4 \\
5\end{array}$ & $\begin{array}{l}\text { (H) } 0.03 \\
\text { (L) } 0.3 \\
\text { (L) } 0.3\end{array}$ & $\begin{array}{l}\text { (H) } 3 \cdot 0 \\
\text { (H) } 3.0 \\
\text { (L) } 3.0\end{array}$ & $\begin{array}{l}1 \cdot 1 \\
1 \cdot 3 \\
1 \cdot 3\end{array}$ & $\begin{array}{l}3 \cdot 0 \\
3 \cdot 0 \\
3 \cdot 0\end{array}$ & $\begin{array}{l}2 \cdot 2(0 \cdot 4) \\
2 \cdot 1(0 \cdot 1) \\
2 \cdot 1(0 \cdot 1)\end{array}$ & $\begin{array}{l}2 \cdot 6(0 \cdot 2) \\
3 \cdot 0(1 \cdot 1) \\
2 \cdot 3(1 \cdot 1)\end{array}$ & $\begin{array}{l}1 \cdot 2(0 \cdot 4) \\
1 \cdot 4(0 \cdot 1) \\
1 \cdot 4(0 \cdot 6)\end{array}$ & $\begin{array}{l}1.4(0.3) \\
2 \cdot 0(0 \cdot 9) \\
1.9(1 \cdot 1)\end{array}$ & $\begin{array}{l}0.4(0.2) \\
0.6(0 \cdot 1) \\
0.5(0 \cdot 2)\end{array}$ & $\begin{array}{l}0.3(0.1) \\
0.6(0 \cdot 2) \\
0.4(0.1)\end{array}$ \\
\hline
\end{tabular}

Values are mean or mean (SD). (H), (L) = Mixture of RISA with hyaluronan $6 \times 10^{6} \mathrm{Da}$ or $2 \times 10^{5} \mathrm{Da}$, respectively. 


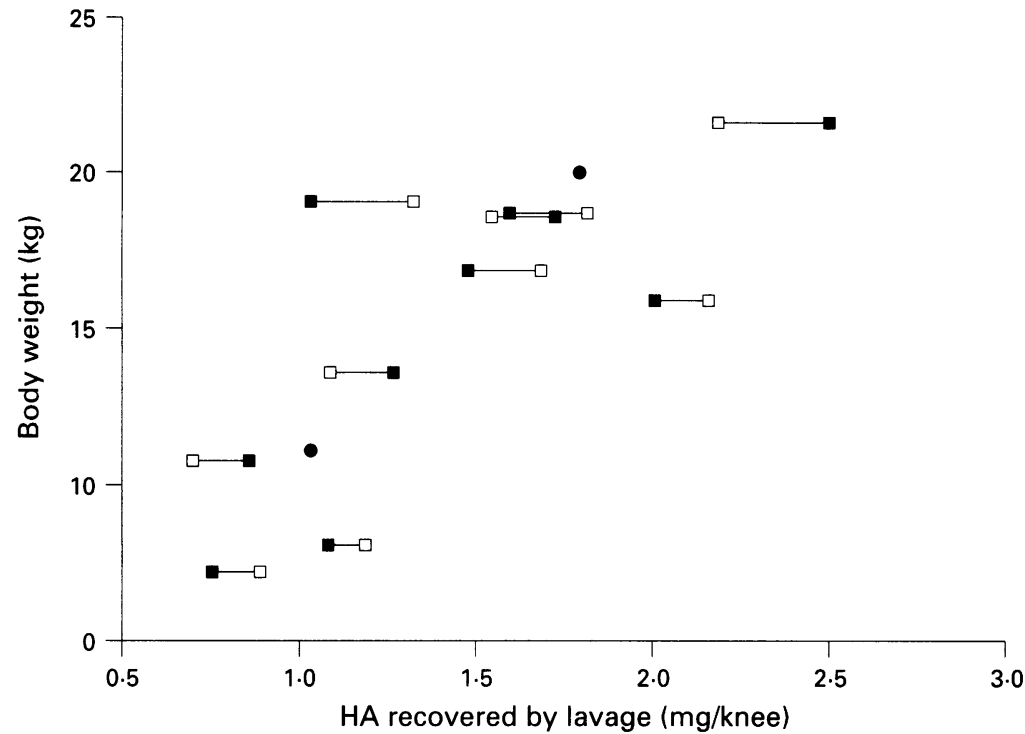

The hyaluronan (HA) content of the synovial fluid in the normal canine knee, determined by saline lavage of left ( $\square$ ) and right ( $\square$ ) knees of $10 \mathrm{dogs}$, and the left knee of two additional dogs (O), related to body weight $(\mathrm{r}=0 \cdot 79, p=0 \cdot 004)$.

$(r=0.79 ; \quad \mathrm{p}=0.004)$. Lavage yielded, on average, $0.9(0.4) \mathrm{mg}$ of hyaluronan from the knees of six dogs with weights $(8-16 \mathrm{~kg}$ ) comparable to those of the dogs used subsequently in studies of RISA clearance. Assuming a physiological hyaluronan concentration of $2.9 \mathrm{mg} / \mathrm{ml}$ (see above), we concluded that the mean synovial fluid volume in the knees of such dogs was $0.3 \mathrm{ml}$.

The mean concentration of hyaluronan in the synovial cavity immediately after RISA-HA $A_{L}$ or RISA-HA $A_{H}$ was injected into the joint (time $t=0$ ) was calculated to be $3.0 \mathrm{mg} / \mathrm{ml}$ in left, and 1.1 or $1.3 \mathrm{mg} / \mathrm{ml}$ in right knees (table). The changes in the average molecular mass of synovial fluid hyaluronan produced by injection of $3.0 \mathrm{mg} / \mathrm{ml}$ RISA-HA or RISA-HA H $\left(0.8 \times 10^{6} ; 4.6 \times 10^{6} \mathrm{Da}\right.$, respectively) had no appreciable effect on RISA $V$ d or clearance.

Although mean values for RISA $V$ d obtained in left and right knees did not differ significantly (table), that in the left knee of each dog tended to be larger than in its right $(p=0.07)$. In left and right knees, mean RISA clearance rates differed by only $23 \%(p>0.05)$ (table). However, the RISA clearance rate in the left knee of each dog, in which the synovial fluid hyaluronan concentration was comparable to that in normal knees, was often greater than that in the contralateral knee which had been injected with 0.03 or $0.3 \mathrm{mg} / \mathrm{ml}$ of RISA-HA or RISA-HA $A_{H}(p=0.01$, Wilcoxon signed rank test).

\section{Discussion}

The concentration of hyaluronan in joint effusions from patients with osteoarthritis and inflammatory arthropathies is less $(0.8-1.7 \mathrm{mg} / \mathrm{ml})$ than that in normal synovial fluid $(1.5-2.9 \mathrm{mg} / \mathrm{ml})^{6} 8$ and its average molecular mass is also reduced. ${ }^{9}{ }^{10}$ Theoreti- cally, steric exclusion of synovial fluid proteins, including those derived from the articular cartilage, from those fractions of the synovial fluid and synovial tissue matrix that are occupied by hyaluronan ${ }^{1112}$ could affect the volume of distribution and clearance of these proteins from the joint. ${ }^{6}$ Non-covalent interactions also have been described between hyaluronan, aggrecan, and a variety of other proteins, including albumin. ${ }^{13}$ Thus the changes in synovial fluid composition seen in arthritic joints could alter the clearance kinetics and synovial fluid concentration of 'marker' molecules.

The results of the present study support this possibility, as a slight but significant decrease in RISA clearance was detected in knees in which the synovial fluid concentration of hyaluronan was reduced to subphysiological values comparable to those seen in human synovial effusions. In this series, changes in the molecular mass of synovial fluid hyaluronan did not have a discernible impact on protein clearance from the normal knee. Because substantial manipulation of synovial fluid hyaluronan in these experiments produced only minor changes in RISA clearance, we conclude that other factors, such as synovitis, joint distension, or involuntary splinting of the painful extremity are probably more significant than hyaluronan as determinants of the kinetics of marker clearance in the arthritic joint.

Supported in part by NIH grant AR 39250 and funds from the Office of Research and Development, Medical Research Service, Department of Veterans Affairs.

1 Saxne T, Heinegard D. Cartilage oligomeric matrix protein: a novel marker of cartilage turnover detectable in synovial a novel marker of cartilage turnover detectable in synot
fluid and blood. Br $\mathcal{\text { Rheumatol }}$ 1992; 31: 583-91.

2 Lohmander L S, Hoerrner L A, Dahlberg L, Roos H, Bjornsson S, Lark M W. Metalloproteinases, tissue
, Bjornsson S, Lark M W. Metalloproteinases, tissue
inhibitor, and proteoglycan fragments in knee synovial inhibitor, and proteoglycan fragments in knee synovial
fluid in human osteoarthritis. Arthritis Rheum 1993; 36: fluid in

3 Thonar E J-M, Shinmei M, Lohmander L S. Body fluid markers of cartilage changes in osteoarthritis. Rheum Dis Clin N Am 1993; 19: 635-57.

4 Saxne T, Heinegard D. Synovial fluid analysis of two groups of proteoglycan epitopes distinguishes early and late cartilage lesions. Arthritis Rheum 1992; 35: 385-90.

5 Lohmander L S. Molecular markers of cartilage turnover: a role in monitoring and diagnosis of osteoarthritis. In: Kuettner K, Schleyerbach R, Peyron J G, Hascall V C, eds. Articular cartilage and osteoarthritis. New York: Raven Press, 1992; 653-62.

6 Levick J R. Synovial fluid: determinants of volume turnover and material concentration. In: Kuettner $\mathrm{K}$, turnover and material concentration. In: Kuettner K,
Schleyerbach R, Peyron J G, Hascall V C, eds. Articular Schleyerbach R, Peyron J G, Hascall V C, eds. Articular
cartilage and osteoarthritis. New York: Raven Press, 1992;

7 Simkin P A, Benedict R S. Iodide and albumin kinetics in normal canine wrists and knees. Arthritis Rheum 1990; 33: 73-9.

8 Davis W H, Lee S L, Sokoloff L. Boundary lubricating ability of synovial fluid in degenerative joint disease. Arthritis Rheum 1978; 21: 754-63.

9 Dahl L B, Dahl I M, Engstrom-Laurent A, Granath K. Concentration and molecular weight of sodium hyaluronate in synovial fluid from patients with hyaluronate in synovial fuid from patients with Dis 1985; 44: 817-22.

10 Bollet A J. The intrinsic viscosity of synovial fluid hyaluronic acid. $\mathcal{F}$ Lab Clin Med 1956; 48: 721-8.

11 Laurent T C, Ogston A G. The interaction between polysaccharides and other macromolecules. 9 . The exclusion saccharides and other macromolecules. 9. The exclusion Biochem ₹ 1964; 93: 106-12.

12 Scott J E, Cummings C, Brass A, Chen Y. Secondary and tertiary structures of hyaluronan in aqueous solution, investigated by rotary shadowing-electron microscopy and computer simulation. Biochem $\mathcal{f}$ 1991; 274: 699-705.

13 Laurent T C, Ogston A G. The interaction between polysaccharides and other macromolecules. 4. The osmotic pressure of mixtures of serum albumin and hyaluronic acid. Biochem $\mathcal{F}$ 1963; 89: 249-53. 